\title{
Antibacterial potential of biosynthesised silver nanoparticles using Avicennia marina mangrove plant
}

\author{
M. Gnanadesigan • M. Anand - S. Ravikumar • \\ M. Maruthupandy $\cdot$ M. Syed Ali $\cdot$ V. Vijayakumar • \\ A. K. Kumaraguru
}

Received: 27 October 2011/Accepted: 25 November 2011/Published online: 13 December 2011

(C) The Author(s) 2011. This article is published with open access at Springerlink.com

\begin{abstract}
The present study was aimed to identify the antibacterial potential of biosynthesised silver nanoparticles using different plant parts (leaves, bark and root) of Avicenna marina mangrove plant. Of the selected three different parts, the leaf extract showed the maximum synthesis of silver nanoparticles. The in vitro antibacterial assay (100 $\mu \mathrm{g} \mathrm{disk}^{-1}$ concentration) showed the results of maximum zone of inhibition with the E. coli $(18.40 \pm 0.97 \mathrm{~mm})$, and minimum $(10.87 \pm 1.33 \mathrm{~mm})$ zone of inhibition with $S$. aureus but the concentrations of MIC and MBC values ranged between 6.25 and $50.0 \mu \mathrm{g} \mathrm{ml}^{-1}$ between the selected bacterial strains. The FTIR results of most potent leaf extract-synthesized silver nanoparticles showed the prominent peaks $(620.967 ; 1,061.02 ; 1,116.58 ; 1,187.94$; $1,280.50 ; 1,353.79 ; 1,384.64 ; 1,598.50 ; 1,629.56 ; 2,854.14$ and 2,927.42) in different ranges. Further, the results of XRD analysis showed the $2 \theta$ intense values (38.11 and 70.57) within the ranges of Bragg's reflection. In addition, the AFM analysis showed the results of particle sizes $(71-110 \mathrm{~nm})$, particle roughness $(11.8 \mathrm{~nm})$, maximum
\end{abstract}

\footnotetext{
M. Gnanadesigan ( $)$ · M. Anand · M. Maruthupandy ·

A. K. Kumaraguru

School of Energy, Environmental and Natural Resources, Department of Marine and Coastal Studies, Madurai Kamaraj University, Madurai 625021, Tamil Nadu, India

e-mail: contact.desigan@gmail.com

S. Ravikumar - M. Syed Ali

School of Marines Sciences, Department of Oceanography and Coastal Area Studies, Thondi Campus, Thondi 623409, Ramanathapuram District, Tamilnadu, India

V. Vijayakumar

School of Chemistry, Department of Inorganic Chemistry, Madurai Kamaraj University, Madurai 625021, Tamil Nadu, India
}

height of the particle roughness $(111.8 \mathrm{~nm})$, and average maximum height of the particle roughness $(57.5 \mathrm{~nm})$. It can be concluded from the present findings that, the biosynthesis of silver nanoparticles from the leaf extract of A. marina can be used as potential antibacterial agents.

Keywords Biosynthesis - Antibacterial · Avicennia marina $\cdot$ Silver nanoparticles

\section{Introduction}

Nanoparticles play an important role in pharmaceutical, industrial and biotechnological applications. In particular, silver nanoparticles are proved to have potential antibacterial, antifungal and antiplasmodial and larvicidal properties (Saxena et al. 2010; Elumalai et al. 2010). But the synthesis of nanoparticles using chemical and physical methods requires high pressure, energy, temperature and toxic chemicals. In this regard, plants and plant part extracts based biosynthesis has been found to be cost effective and environmental friendly (Casida and Quistad 2005). But studies related to the synthesis of nanoparticles using mangrove sand mangrove associate plants are very limited. Marine environmental conditions are extremely different from terrestrial ones; it is surmised that mangrove plants have different characteristics from those of terrestrial plants, and therefore, might produce different types of bioactive compounds (Gnanadesigan et al. 2011a; Ravikumar et al. 2011a, b). Among the different mangrove plants, Avicennia marina is previously proved to have antibacterial, antiplasmodial, antiviral activities (Ravikumar et al. 2011c) and also it is proved to have high content of secondary metabolites such as polyphenols, flavonoids, alkaloids and tannins (Ravikumar et al. 2010). In this connection, the present study made

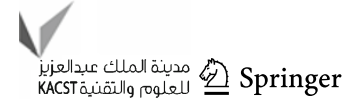


an attempt to identify the antibacterial potential of biosynthesised silver nanoparticles using different plant parts of Avicennia marina mangrove plant.

\section{Materials and methods}

\section{Collection of plant material}

Different plant parts (leaves, bark and root) of A. marina were collected from Karangadu mangrove forest (latitude $9^{\circ} 38^{\prime} \mathrm{N}$ and longitude $78^{\circ} 57^{\prime} \mathrm{E}$ ), South East coast of India, Ramanathapuram district, Tamilnadu, India. The authentication of the plant species was done by Prof. K. Kathiresan, Centre of Advanced Study in Marine Biology, Annamalai University, Porto Novo, Tamil Nadu, India. The voucher specimen (MKUCMS0024) was also maintained in the Department of Marine and Coastal Studies, Madurai Kamaraj University, Madurai, Tamilnadu, India.

Biosynthesis of silver nanoparticles

The collected samples were washed thrice with tap water and twice with distilled water to remove the adhering salts and other associated contaminants. About $10 \mathrm{~g}$ of various plant parts were finely cut into small pieces and boiled with $100 \mathrm{ml}$ of double sterilized distilled water separately for $5 \mathrm{~min}$. The boiled extracts were filtered through Whatmann no. 1 filter paper. A total of $10 \mathrm{ml}$ of collected filtrate was treated with $90 \mathrm{ml}$ of silver nitrate aqueous solution $(21.2 \mathrm{~g}$ of $\mathrm{AgNO}_{3}$ powder in $125 \mathrm{ml}$ of Milli Q water) and incubated at room temperature for $10 \mathrm{~min}$, resulting in the formation of brownish yellow color indicating the synthesis of silver nanoparticles (Parashar et al. 2009). After that, about $1 \mathrm{ml}$ (diluted with 1:20 V/V Milli Q water) of different plant-part-synthesised silver nanoparticle solution was monitored in UV-Vis spectrophotometer (between 300 and $700 \mathrm{~nm}$ with $5 \mathrm{~nm}$ intervals) with different time intervals (15 and $30 \mathrm{~min} ; 4,6$ and $8 \mathrm{~h}$ ). After $8 \mathrm{~h}$ of incubation, the solution was centrifuged with $12,000 \mathrm{rpm}$ for $20 \mathrm{~min}$, and their pellets were re dispersed in sterile distilled water. The centrifugation and redispersion was repeated three times to ensure the complete separation of nanoparticles.

In vitro antibacterial activity

The in vitro antibacterial activity was performed with the leaf extract (the maximum silver nanoparticle producer) synthesised silver nanoparticles, and chemically synthesized silver nanoparticle (obtained from Department of Inorganic Chemistry, Madurai Kamaraj University, Madurai). In brief, $5 \mathrm{ml}$ suspension of nanoparticles $\left(5 \mathrm{mg} \mathrm{ml}^{-1}\right)$ was sonicated and subsequently filtered through a membrane filter
$(0.2 \mu \mathrm{m}, 47 \mathrm{~mm}$ diameter, Sartorius filter paper). The nanoparticles laden filter paper was dried in an oven for $1 \mathrm{~h}$, and small disks of uniform size $(6 \mathrm{~mm}$ dia) containing $100 \pm 15 \mu \mathrm{g}$ nanoparticles were punched out, and stored in a desiccator at room temperature. Five different human bacterial pathogens such as E. coli, Pseudomonas aeruginosa, Staphylococcus aureus, Strptococcus pyogens and Bacillus subtilus $\left(100 \mu \mathrm{l}\right.$ of $\left.10^{6} \mathrm{CFU} \mathrm{ml}{ }^{-1}\right)$ were spread over the nutrient agar plate, before placing the disks on the plate. The plates were incubated at $35^{\circ} \mathrm{C}$ for $24 \mathrm{~h}$, after which the average diameter of the inhibition zone surrounding the disk was measured. The mean and standard deviation (SD) were reported for each bacterial strain based on six replicates. Minimum inhibitory concentration (MIC) was also carried out with the leaf extract-synthesized silver nanoparticles. In brief, about $0.5 \mathrm{ml}$ of various concentrations $\left(3.125,6.25,12.5,25,50,100,200\right.$ and $400 \mu \mathrm{g} \mathrm{ml}^{-1}$ ) of the leaf extract-synthesized silver nanoparticle was prepared with dimethyl sulphoxide (DMSO), and mixed with $50 \mu \mathrm{l}$ of $24 \mathrm{~h}$ old bacterial pathogens individually and incubated at $37^{\circ} \mathrm{C}$ for $48 \mathrm{~h}$ individually. To calculate the MIC, turbidity due to bacterial growth was observed in each concentration. To avoid the possibility of misinterpretations due to the turbidity of insoluble compounds, the minimum bactericidal concentration (MBC) was determined by subculturing the MIC dilutions onto the sterile agar plates. The lowest concentration of the extracts which inhibits the growth of tested bacteria is observed and tabulated.

\section{Characterization of bio synthesised silver nanoparticles}

The purified pellet was dried and subjected to the FTIR spectroscopy measurement in the diffuse reflectance mode at a resolution of $4 \mathrm{~cm}^{-1}$ in $\mathrm{KBr}$ pellets. The dried mixture of silver nanoparticles was further analyzed with X-ray diffractometer (PANalytical BV, The Netherlands) operated at a voltage of $40 \mathrm{kV}$, and a current of $30 \mathrm{~mA}$, with $\mathrm{Cu}$ $\mathrm{K} \alpha$ radiation in a $\theta-2 \theta$ configuration. In addition, a thin film of sample was also prepared in the cover slip with $100 \mu \mathrm{l}$ synthesised silver nanoparticles solution, and allowed to dry for $5 \mathrm{~min}$, and the slides were analyzed with atomic force microscopy.

\section{Results}

The color intensity of the synthesised silver nanoparticles increased with the increased time duration. Of the selected three different plant parts, the leaf extract showed maximum level of OD value (1.39) after $8 \mathrm{~h}$ of incubation (Fig. 1). The results of disk diffusion assay showed the maximum zone of inhibition with the E. coli $(18.40 \pm 0.97 \mathrm{~mm})$, followed by Pseudomonas aeruginosa $(17.64 \pm 0.91 \mathrm{~mm})$ but the 


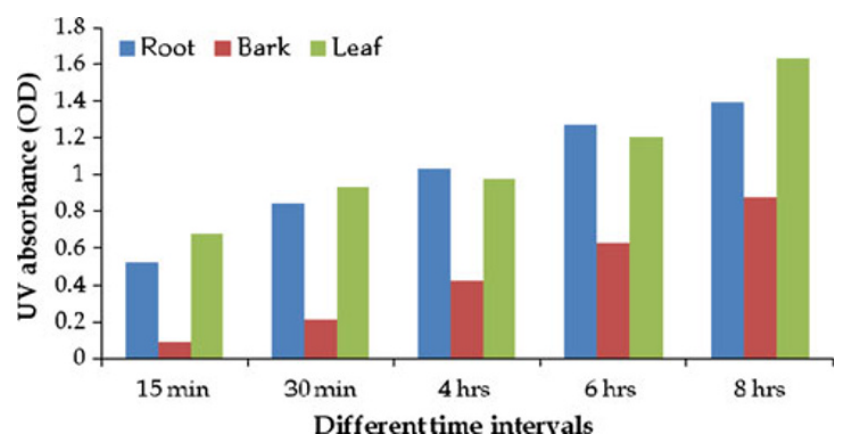

Fig. 1 UV-Vis spectral analysis of silver nanoparticles using various plant parts of A. marina extracts

minimum zone $(10.87 \pm 1.33 \mathrm{~mm})$ of inhibition was identified with the Staphylococcus aureus species. Further, the resulted concentrations of the MIC and MBC values varied between 6.25 and $50.0 \mu \mathrm{g} \mathrm{ml}^{-1}$ between the organisms. Further, results of antibacterial activity of disk diffusion assay, MIC and MBC with chemically synthesized silver nanoparticles are also comparable with the biosynthesized silver nanoparticle (Table 1). The results of the FTIR spectrum showed prominent peaks with different $(620.967$; $1,061.02 ; 1,116.58 ; 1,187.94 ; 1,280.50 ; 1,353.79 ; 1,384.64$; $1,598.50 ; 1,629.56 ; 2,854.14$ and $2,927.42$ ) values (Fig. 2). The results of XRD $2 \theta$ intense values ranged with different degrees (38.11 and 70.57), and these results correspond to the (111) and (311) Bragg's reflection, respectively (JCPDS NO 03-0931) (Sathishkumar et al. 2009) (Fig. 3). The AFM topology results of the leaf extract-synthesized silver nanoparticles showed the average particle sizes $(71-110 \mathrm{~nm})$, particle roughness $(11.8 \mathrm{~nm})$, maximum height of the particle roughness $(111.8 \mathrm{~nm})$ and average maximum height of the particle roughness $(57.5 \mathrm{~nm})$ (Fig. 4).

\section{Discussion}

Nanotechnology is an emerging trend in the field of science and technology for the manufacturing new materials at nanoscale levels (Tripathi et al. 2009). In the present scenario plant extract based nanoparticles biosynthesis is emerging as novel antimicrobial agents with biological, chemical and physical properties (Gong et al. 2007; Krishnaraj et al. 2010). In view of this, the present study aimed to make an attempt to identify the synthesis and antibacterial properties of silver nanoparticles using the various parts of A. marina mangrove plant. Of the selected different parts, the leaf extract showed maximum yield of silver nanoparticles than the bark and root aqueous extracts, and this might be due to the presence of high content of secondary metabolites such as polyphenols, flavonoids and tannins (Gnanadesigan et al. 2011b; Ravikumar et al. 2009; Ravikumar and Gnanadesigan 2011). Further, the biosynthesis of silver nanoparticles can be confirmed by the formation of yellowish brown color, and this might be due to the excitation of the surface plasmon vibration of the synthesised silver nanoparticles (Jayaseelan et al. 2010). In addition, the results of XRD pattern further corroborate the synthesis of silver nanoparticles with sharp bands of Bragg peaks, and this might be due to the stabilization of the synthesised nanoparticles by the various reducing agents of the A. marina leaf extract, and thus provides the crystallization nature of the silver nanoparticles (Asmathunisha et al. 2010). Further, the results of the FTIR values of synthesised silver nanoparticles showed the presence of various functional groups such as alkane groups, methylene groups, alkene groups, amine groups and carboxylic acids, and these functional groups are the major classes in many of the chemical groups and these chemical groups are previously proved to have potential reducing agents in the synthesis of silver nanoparticles (Cho et al. 2005). Moreover, the present study also proved to have potential antibacterial activities with the A. marina aqueous leaf extract synthesised silver nanoparticles and this might be due to denaturation of bacterial cell wall, blocking bacterial respiration, destabilization of outer membrane and depletion of intracellular ATP (Vivekanandhan et al. 2009). Further, the variation of the sensitivity between Gram positive and negative bacterial

Table 1 In vitro antibacterial potential of biosynthesized silver nanoparticles using A. marina leaf extract

\begin{tabular}{|c|c|c|c|c|c|c|}
\hline \multirow[t]{2}{*}{ Pathogens } & \multicolumn{3}{|c|}{ A. marina leaf extract } & \multicolumn{3}{|c|}{ Chemically synthesized silver nanoparticle } \\
\hline & $\begin{array}{l}\text { Disk diffusion } \\
\text { assay (mm dia) }\end{array}$ & $\begin{array}{l}\text { MIC } \\
\left(\mu \mathrm{g} \mathrm{ml}^{-1}\right)\end{array}$ & $\begin{array}{l}\text { MBC } \\
\left(\mu \mathrm{g} \mathrm{ml}^{-1}\right)\end{array}$ & $\begin{array}{l}\text { Disk diffusion } \\
\text { assay (mm dia) }\end{array}$ & $\begin{array}{l}\text { MIC } \\
\left(\mu \mathrm{g} \mathrm{ml}^{-1}\right)\end{array}$ & $\begin{array}{l}\mathrm{MBC} \\
\left(\mu \mathrm{g} \mathrm{ml}^{-1}\right)\end{array}$ \\
\hline E. coli & $18.40 \pm 0.97$ & $6.25 \pm 0.00$ & $12.5 \pm 0.00$ & $22.20 \pm 0.75$ & $3.125 \pm 0.00$ & $3.125 \pm 0.00$ \\
\hline Pseudomonas aeruginosa & $17.64 \pm 0.91$ & $12.5 \pm 0.00$ & $50.0 \pm 0.00$ & $19.64 \pm 1.98$ & $12.5 \pm 0.00$ & $25.0 \pm 0.00$ \\
\hline Staphylococcus aureus & $10.87 \pm 1.33$ & $25.0 \pm 0.00$ & $50.0 \pm 0.00$ & $14.90 \pm 1.24$ & $25.0 \pm 0.00$ & $50.0 \pm 0.00$ \\
\hline Klebsiella sp & $14.65 \pm 1.09$ & $6.25 \pm 0.00$ & $25.0 \pm 0.00$ & $17.65 \pm 2.19$ & $3.125 \pm 0.00$ & $6.25 \pm 0.00$ \\
\hline Bacillus subtilus & $13.93 \pm 0.84$ & $25.0 \pm 0.00$ & $50.0 \pm 0.00$ & $13.93 \pm 1.38$ & $12.5 \pm 0.00$ & $25.0 \pm 0.00$ \\
\hline
\end{tabular}

Values \pm SD indicates the replicates of three experiments 


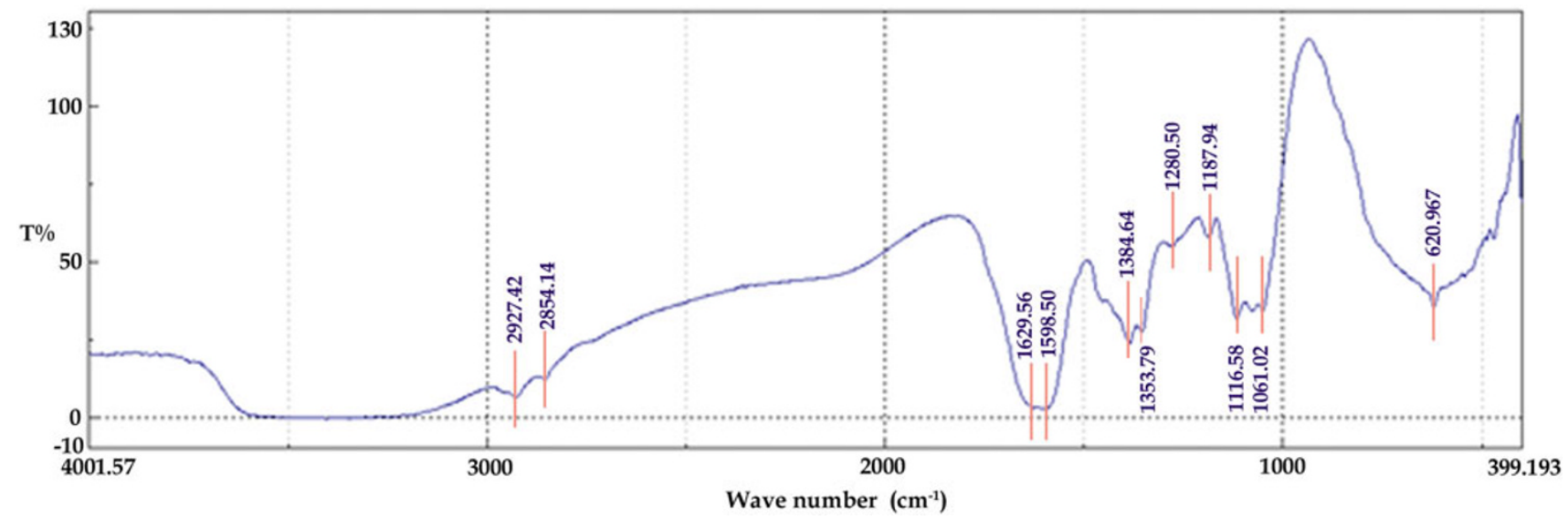

Fig. 2 FTIR spectrum analysis of biosynthesised silver nanoparticles using A. marina leaf extract. Values indicate the functional groups of various compounds

Fig. 3 XRD analysis of biosynthesised silver nanoparticles using A. marina leaf extract

Fig. 4 AFM analysis of bio synthesised silver nanoparticles using A. marina leaf extract. Numbers indicate the different sizes of nanoparticles between 71 and $110 \mathrm{~nm}$ ranges

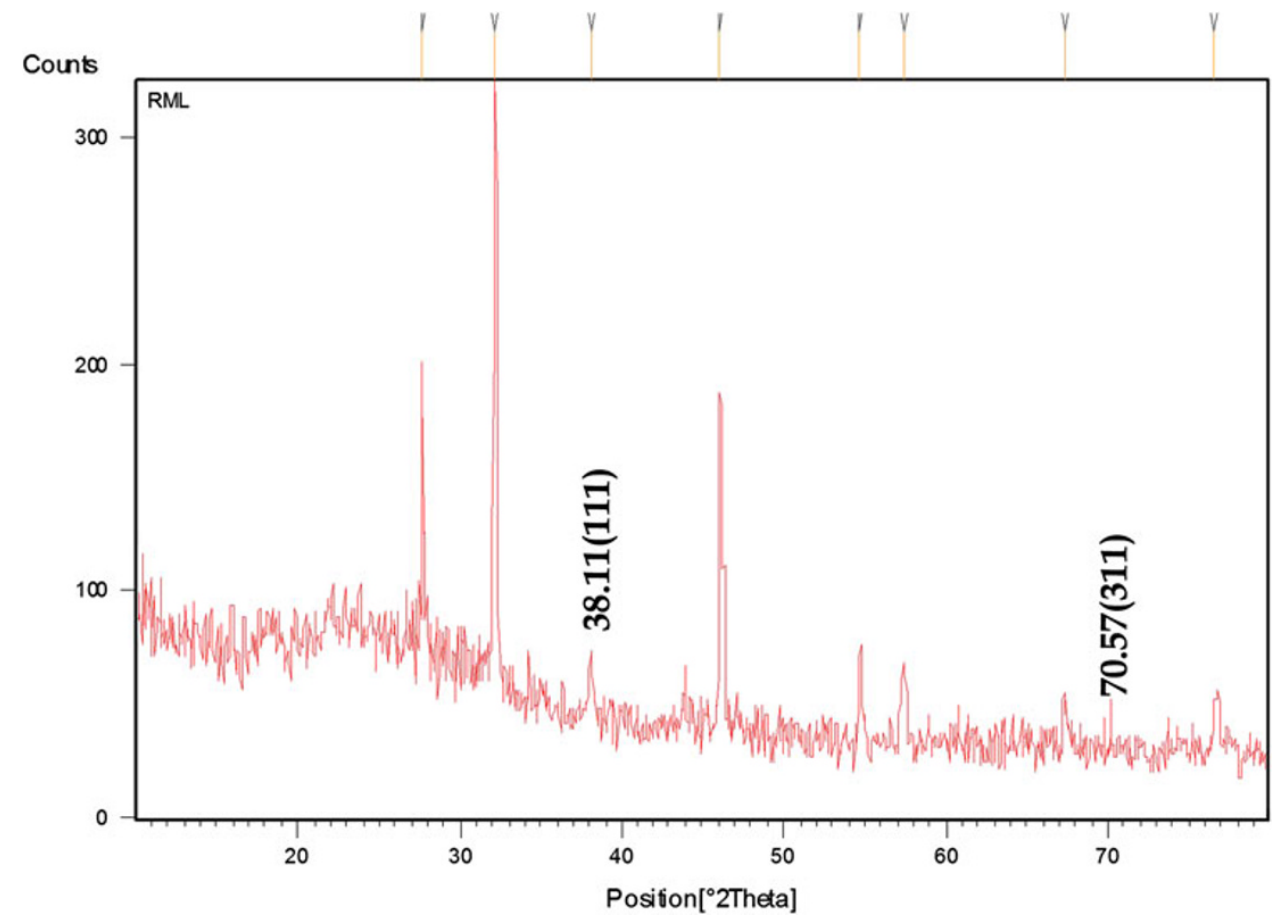

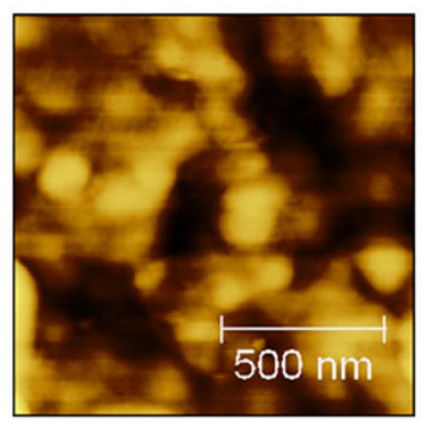

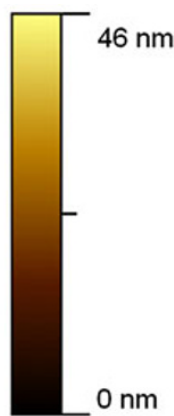

isolates might be attributed by the membrane permeability (Ravikumar et al. 2010). In spite of this permeability barrier, the synthesized silver nanoparticles exhibited the strong inhibition with gram-negative bacterial strains. The size and shape of nanoparticles play an important role in many of the pharmaceutical applications. In this regard, the 
size of the synthesised nanoparticles was identified between 71 and $110 \mathrm{~nm}$ with various spherical shapes, which falls closer to many of the silver nanoparticles produced by other plant materials (Vivekanandhan et al. 2009; Tripathi et al. 2009; Gnanadesigan et al. 2011a). It is concluded from the present findings that, the biosynthesized silver nanoparticles using leaf aqueous extract of $A$. marina showed potential antibacterial activity with various bacterial pathogens which could be further used as a potential antibacterial agents.

Acknowledgments The authors are thankful to the authorities of Madurai Kamaraj University for providing required facilities and Prof. S. Shanmugasundaram and Mr. B. K. Balachandar, Lab Assistant, School of Biological Sciences, Department of Microbial Technology, Madurai Kamaraj University, Tamil Nadu, India for providing the AFM analysis.

Open Access This article is distributed under the terms of the Creative Commons Attribution License which permits any use, distribution and reproduction in any medium, provided the original author(s) and source are credited.

\section{References}

Asmathunisha N, Kathiresan K, Anburaj R, Nabeel MA (2010) Synthesis of antimicrobial silver nanoparticles by callus leaf extracts from saltmarsh plant Sesuvium portulacastrum L. Coll Surf B Biointer 79:488-493

Casida JE, Quistad GB (2005) Insecticide targets: learning to keep up with resistance and changing concepts of safety. Agric Chem Biotechnol 43:185-191

Cho K, Park J, Osaka T, Park S (2005) The study of antimicrobial activity and preservative effects of nanosilver ingredient. Electrochim Acta 51:956-960

Elumalai EK, Prasad TNVKV, Hemachandran J, Therasa SV, Thirumalai T, David E (2010) Extracellular synthesis of silver nanoparticles using leaves of Euphorbia hirta and their antibacterial activities. J Pharm Sci Res 2(9):549-554

Gnanadesigan M, Anand M, Ravikumar S, Maruthupandy M, Vijayakumar V, Selvam S, Dhineshkumar M, Kumaraguru AK (2011a) Biosynthesis of silver nanoparticles using mangrove plant extract and their potential mosquito larvicidal property. Asian Pac J Trop Med 4(10):799-803

Gnanadesigan M, Ravikumar S, Jacob Inbanesan S (2011b) Hepatoprtective and antioxidant properties of marine halophyte Luminetzera racemosa bark extract in $\mathrm{CCL}_{4}$ induced heaptotoxicity. Asian Pac J Trop Med 1(5):462-465
Gong P, Li H, He X, Wang K, Hu J, Tan W, Zhang S, Yang X (2007) Preparation and antibacterial activity of $\mathrm{Fe}_{3} \mathrm{O}_{4} @ \mathrm{Ag}$ nanoparticles. Nanotechnol 18:604-611

Jayaseelan C, Rahuman A, Rajakumar G, Kirthi AV, Santhoshkumar T, Marimuthu S, Bagavan A, Kamaraj C, Zahir A, Elango G (2010) Synthesis of pediculocidal and larvicidal silver nanoparticles by leaf extract from heart leaf moon seed plant, Tinospora cordifolia Miers. Parasitol Res 107:585-592

Krishnaraj C, Jagan EG, Rajasekar S, Selvakumar P, Kalaichelvan PT, Mohan N (2010) Synthesis of silver nanoparticles using Acalypha indica leaf extracts and its antibacterial activity against water borne pathogens. Coll Surf B Biointer 76(1):50-56

Parashar UK, Saxenaa PS, Srivastava A (2009) Bioinspired synthesis of silver nanoparticles. Dig J Nanomater Biostruct 4:159-166

Ravikumar S, Gnanadesigan M (2011) Hepatoprotective and antioxidant activity of mangrove plant Lumnitzera racemosa. Asian Pac J Trop Biomed 1(4):348-352

Ravikumar S, Ramanathan G, Subakaran M, Jacob Inbaneson S (2009) Antimicrobial compounds from marine halophytes for silkworm disease treatment. Int J Med Med Sci 1(5):184-191

Ravikumar S, Gnanadesigan M, Suganthi P, Ramalakshmi A (2010) Antibacterial potential of chosen mangrove plants against isolated urinary tract infectious bacterial pathogens. Int J Med Med Sci 2(3):94-99

Ravikumar S, Jacob Inbaneson S, Suganthi P, Gnanadesigan M (2011a) In vitro antiplasmodial activity of ethanolic extracts of mangrove plants from South East coast of India against chloroquinesensitive Plasmodium falciparum. Parasitol Res 108:873-878

Ravikumar S, Jacob Inbaneson S, Suganthi P, Venkatesan M, Ramu A (2011b) Mangrove plant source as a lead compounds for the development of new antiplasmodial drugs from South East coast of India. Parasitol Res 108:1405-1410

Ravikumar S, Ramanathan G, Gnanadesigan M, Ramu A, Vijayakumar V (2011c) In vitro antiplasmodial activity of methanolic extracts from seaweeds of South West coast of India. Asian Pac J Trop Med 4(11):862-865

Sathishkumar M, Sneha K, Won SW, Cho CW, Kim S, Yun YS (2009) Cinnamon zeylanicum bark extract and powder mediated green synthesis of nano-crystalline silver particles and its bactericidal activity. Coll Surf B Biointer 73(2):332-338

Saxena A, Tripathi RM, Singh RP (2010) Biological synthesis of silver nanoparticles using onion (Allium cepa) extract and their antibacterial activity. Dig J Nanomater Bios 5(2):427-432

Tripathi A, Chandrasekaran N, Raichur AM, Mukherjee A (2009) Antibacterial applications of silver nanoparticles synthesized by aqueous extract of Azadirachta indica (Neem) leaves. J Biomed Nanotechnol 5(1):93-98

Vivekanandhan S, Misra M, Mohanty AK (2009) Biological synthesis of silver nanoparticles using Glycine max (soybean) leaf extract: an investigation on different soybean varieties. J Nanosci Nanotechnol 9(12):6828-6833 